九州大学学術情報リポジトリ

Kyushu University Institutional Repository

\title{
2015 Nationwide Survey Revealed Barley stripe mosaic virus in Korean Barley Fields
}

Lim, Hyo-Jin

Department of Applied Biology, College of Agriculture and Life Sciences, Chungnam National University

Seo, Eun-Young

Department of Applied Biology, College of Agriculture and Life Sciences, Chungnam National University

Kim, Hyun-Seung

Department of Applied Biology, College of Agriculture and Life Sciences, Chungnam National University

Kin, Jung-Kyu

Department of Applied Biology, College of Agriculture and Life Sciences, Chungnam National University

他

https://doi.org/10.5109/1564085

出版情報: 九州大学大学院農学研究院紀要. 61 (1)，pp.71-77，2016-02-29. Faculty of Agriculture， Kyushu University

バージョン :

権利関係 : 


\title{
2015 Nationwide Survey Revealed Barley stripe mosaic virus in Korean Barley Fields
}

\author{
Hyo-Jin LIM ${ }^{1}$, Eun-Young SEO ${ }^{1}$, Hyun-Seung KIM${ }^{1}$, Jung-Kyu KIM ${ }^{1}$, Chan-Hwan PARK ${ }^{1}$, \\ Jun-Su GONG ${ }^{1}$, Ik-hyun KIM ${ }^{1}$, Sang-huk HAN ${ }^{1}$, James P. KILCREASE ${ }^{2}$, \\ Naruto FURUYA ${ }^{3 *}$, Kenichi TSUCHIYA ${ }^{3 *}$, John HAMMOND ${ }^{2 *}$ \\ and Hyoun-Sub LIM ${ }^{1 *}$
}

\author{
Laboratory of Plant Pathology, Division of Agricultural Bioresource Science, \\ Department of Bioresource Science, Faculty of Agriculture, \\ Kyushu University, Fukuoka 812-8581, Japan \\ (Received November 16, 2015 and accepted November 19, 2015)
}

\begin{abstract}
A seed-transmitted virus has consistently caused significant economic damage to barley crops in Korea in recent years, and may be increasing because many farmers save seed for replanting. Because some barley seed is imported, there is the potential for introduction of new seed-transmitted viruses, causing diseases which may spread. Barley cultivation in South Korea is expanding nationwide due to the increasing popularity of health foods, so both production and quality of barley grain is important. Although Barley stripe mosaic virus (BSMV) has been reported previously as a small percentage of all barley viruses present in Korea, increases in imports of barley seed may lead to increased occurrence of this seed-transmitted virus. We therefore investigated the virus status of barley crops around Iksan and Wanju. On several newly cultivated barley farms, we observed areas showing symptoms typical of BSMV, and confirmed BSMV infection in $24 \%$ of the samples examined. In order to understand the occurrence and seed transmission of Korean BSMV isolates, we examined sequence variation within the Triple Gene Block proteins, and subcellular localization of two of these proteins. The newly identified Korean BSMV isolates show low sequence variability and high sequence homology to previously reported US isolates. With these results, we expect to confirm distribution of barley viruses and possible emerging viruses, which will serve as base line data to document virus prevention and control measures.
\end{abstract}

Key words: Barley stripe mosaic virus, Nationwide survey, Seed transmission

\section{INTRODUCTION}

Popularity of health foods is increasing in South Korea. Accordingly, cultivation of barley and other crops is expanding nationwide in South Korea. Barley is also the most widely used cereal crop for the brewing industry, and malting is an essential step for the production of beer and wines. Therefore production and quality of barley is highly important. Historically, Barley diseases occurring in Korea have been known to be caused by fungi like smut (Ustilago hordei, U. nuda), powdery mildew (Erysiphe graminis), and scab (Fusarium graminearum). More recently it has been shown that virus infections also cause disease in barley fields.

Viruses affecting barley are reported to be spread by soil transmission (Barr and Slykhuis, 1976; Chen et al., 1991), insect transmission (Kojima et al., 1983), and seed transmission (Na, 1979; Lundsgaad, 1976). Viruses which are soil transmitted include Barley yellow mosaic

\footnotetext{
1 Department of Applied Biology, College of Agriculture and Life Sciences, Chungnam National University, Daejeon 305-764, Republic Korea

2 United States Department of Agriculture - Agricultural Research Service, United States National Arboretum, Floral and Nursery Plants Research Unit, Beltsville, MD 20705, USA

3 Department of Agricultural Bioresource Science, Kyushu University, 6-10-1, Hakozaki, Fukuoka, 812-8581, Japan

${ }^{1 *}$ Corresponding Author (E-mail: hyounlim@cnu.ac.kr)

2* Corresponding Author (E-mail: john.hammond@usda.ars.gov)

${ }^{3 *}$ Corresponding Author (E-mail: kentsuch@agr.kyushu-u.ac.jp)
}

virus (BaYMV), Barley mild mosaic virus (BaMMV), Soil borne wheat mosaic virus (SBWMV), Wheat yellow mosaic virus (WYMV), Wheat spindle streak mosaic virus (WSSMV), Wheat streak mosaic virus (WSMV), and Wheat green mosaic virus (WMoV). Viruses transmitted by insects include Northern cereal mosaic virus (NCMV) and Barley yellow dwarf virus (BYDV); while Barley stripe mosaic virus (BSMV) is transmitted through seed $(\mathrm{Na}, 1979)$ and most of the virus transmission in Korea is via soil (So et al., 1997). Around 1999, about 40\% of barley was infected by soil transmission virus in southern barley fields. Barley production had been reduced by $40-100 \%$ as a result (Park et al., 2005; Frahm, 1989; Ha, 1999). From 2012 to 2014, there are no reports of introduced virus in Korea barley fields, and in the past three years, occurrence of barley virus has been average. The dominant viruses have been BaYMV in barley and SBWMV in wheat as in previous years. On the other hand, BSMV has not emerged frequently in Korea (NICS, 2014). The first reported occurrence of BSMV in Korea was in 1979, with the level of BSMV in the infected cultivars varying from $2 \sim 35 \%$ (Na, 1979); since then, BSMV infections have been reported at a low rate (NICS, 2014). In spite of the fact that BSMV usually occurs in the form of mild strains and infection is often symptomless, the crop losses due to the infections may be important. If BSMV infection rate is low, farmers still need to use caution when saving seed, because this disease can occur serious yield losses in subsequent years if infected seed is planted. 
BSMV is well-known to be seed-transmitted. Serological assays detected BSMV in covered, naked, and malting barley as well as in wheat (Na, 1979). Korean farmers typically save seed for replanting, potentially increasing levels of infection. However, the proportion of imported seed has been increasing. In case of Tworowed barley, most seed was Korean grown prior to 1985. By 1999, about 50\% of seed was imported (Ha, 1999). Consequently, seed-transmitted virus may be brought into the country and subsequently spread.

BSMV is the type member of the genus Hordeivirus, with a wide geographic distribution. Hordeiviruses have positive-sense, single-stranded RNA genomes consisting of three genome components, designated $\alpha, \beta$, and $\gamma$. Barley is the main host of BSMV but the virus can infect also wheat and rye (Slykhuis, 1976). BSMV is primarily dependent on seed transmission in barley for its survival in nature, as there are no known vectors involved in the virus transmission. However, BSMV can be efficiently transmitted mechanically, e.g. by foliage contact in a field (Jeżewska and Trizmiel, 2009), so damage can increase in the field.

We therefore investigated the virus status of crops in barley fields by collecting leaves with virus-like symptoms from the field. On several newly cultivated barley farms we observed several areas showing symptoms typical of BSMV. A total of 83 barley and rye tissue samples were assayed by RT-PCR using specific primers for BSMV, and BSMV infection was confirmed in 20 samples. In order to understand occurrence and properties of Korean BSMV isolate seed transmission in Korea, we identified sequence variation within the Triple Gene Block (TGB; associated with viral movement) and subcellular localization of the TGB2 and TGB3 proteins. The newly characterized Korean BSMV isolates have little sequence variability and high sequence homology to previously reported US isolates. There were not significant differences of subcellular localization between BSMV ND18 strain and the Korean isolate. With these results, we expect to confirm distribution of common viruses and possible emerging viruses, which will serve as base line data for virus prevention and control measures.

\section{MATERIALS AND METHODS}

\section{COLLECTION OF VIRUS-INFECTED BARLEY SAMPLES}

Barley and rye samples were collected from leaves with virus-like symptoms in the field. A nationwide survey was performed in March and April of 2015. We collected 83 barley and rye samples from newly-cultivated barley fields in 13 cities (Fig. 1) to maximize the detection of seed-transmitted viruses. Samples were collected from the locations and crops (barley or rye) shown in Table 1, from plants showing stripe, stunt, and yellow mottle symptoms (Table 1, Fig. 2). Typical barley and rye symptoms were vertical stripe on leaves and purple edge of leaves.

\section{RNA EXTRACTION AND RT-PCR}

Total RNA was extracted from leaves of barley and rye using Trizol reagent (MRC), and cDNA was synthesized with TOYOBO ReverTra Ace $-\alpha$. RT-PCR was performed with specific primers newly designed based on sequences available from GenBank (shown in Table 2) for detection of BSMV, BaMMV, BYDV, and BaYMV. PCR conditions were $95^{\circ} \mathrm{C} 30 \mathrm{sec}, 56^{\circ} \mathrm{C} 30 \mathrm{sec}, 72^{\circ} \mathrm{C} 30 \mathrm{sec}$, 35 cycle for all primer pairs.

\section{SEQUENCE ANALYSIS}

RNA extracts from each region were grouped

Table 1. Location and host plant of collected sample

\begin{tabular}{cll}
\hline Sample No. & \multicolumn{1}{c}{ Location (province) } & Host plant \\
\hline H0001 H0003 & Gunsan (Jeollabuk-do) & Barley \\
H0004 H0007 & Iksan (Jeollabuk-do) & Barley \\
H0008 H0015 & Wanju (Jeollabuk-do) & Barley \\
H0016 H0017 & Damyang (Jeollanam-do) & Barley \\
H0018 H0019 & Cheonan (Chungcheongnam-do) & Barley \\
H0020 H0023 & Cheonan (Chungcheongnam-do) & Rye \\
H0024 H0031 & Boeun (Chungcheongbuk-do) & Rye \\
H0032 H0041 & Sangju (Gyeongsangbuk-do) & Barley \\
H0042 H0047 & Yeongwol (Gangwon-do) & Rye \\
H0048 H0053 & Donghae (Gangwon-do) & Barley \\
H0054 H0058 & Samcheok (Gangwon-do) & Barley \\
H0059 H0065 & Samcheok (Gangwon-do) & Rye \\
H0066 H0070 & Uljin (Gyeongsangbuk-do) & Rye \\
H0071 H0073 & Uljin (Gyeongsangbuk-do) & Barley \\
H0074 H0079 & Youngduk (Gyeongsangbuk-do) & Barley \\
H0080 H0083 & Geumsan (Chungcheongnam-do) & Barley \\
\hline
\end{tabular}




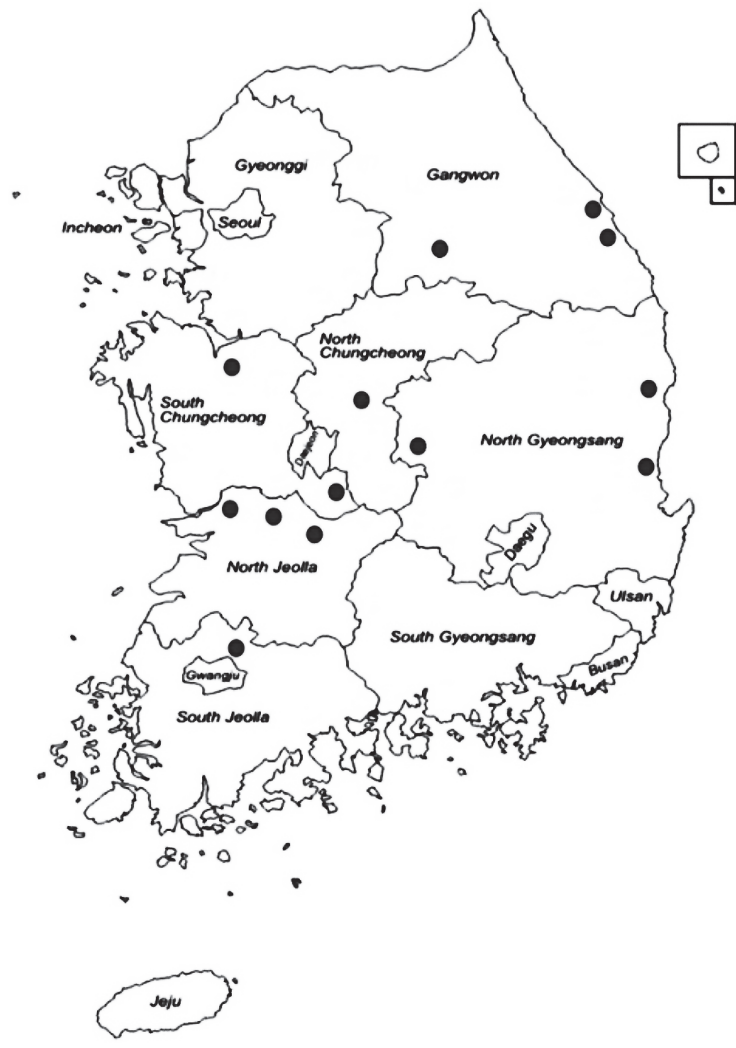

Fig. 1. Geographical distribution of collection sites of barley samples.

together for amplification and analysis of the TGB regions. The respective triple gene block region (BSMV-TGB1, BSMV-TGB2, BSMV-TGB3) of Korean BSMV were amplified using the specific primers (Table 3 ). The respective PCR products were cloned into the T-blunt vector (Solgent), and multiple clones sequenced for each TGB gene from each collection region. The amino acid sequence of the respective triple gene block region were compared to the homologous sequence of BSMV strain ND18 by the Align Sequences Nucleotide BLAST program within the National Center for Biotechnology Information (http://blast.ncbi.nlm.nih.gov/Blast.cgi).

\section{PHYLOGENETIC ANALYSIS}

Phylogenetic trees were inferred on the basis of neighbor-joining methods following Han et al. (2015). We did 1,000 bootstrap replicates for each tree. All phylogenetic trees were constructed with MEGA version 6 (Tamura et al., 2013). Amino acid sequences of TGB1, TGB2, and TGB3 of each of 8 strains used in the phylogenetic analysis were obtained from GenBank.

\section{CONSTRUCTION OF BSMV-TGB3 AND BSMV- TGB2/3 WILD TYPE AND MUTANTS}

The BSMV-TGB3 region was amplified using primers BSMV-TGB3-F/BSMV-TGB3-R, digested with XhoI and BamHI and and substituted into pGDG:MCS region, creating pGDG:BSMV TGB3. We created two constructs in pGDG with TGB3 WT, and TGB3 L149P (the unique Korean TGB3 sequence). The WT BSMV-TGB2/3 and
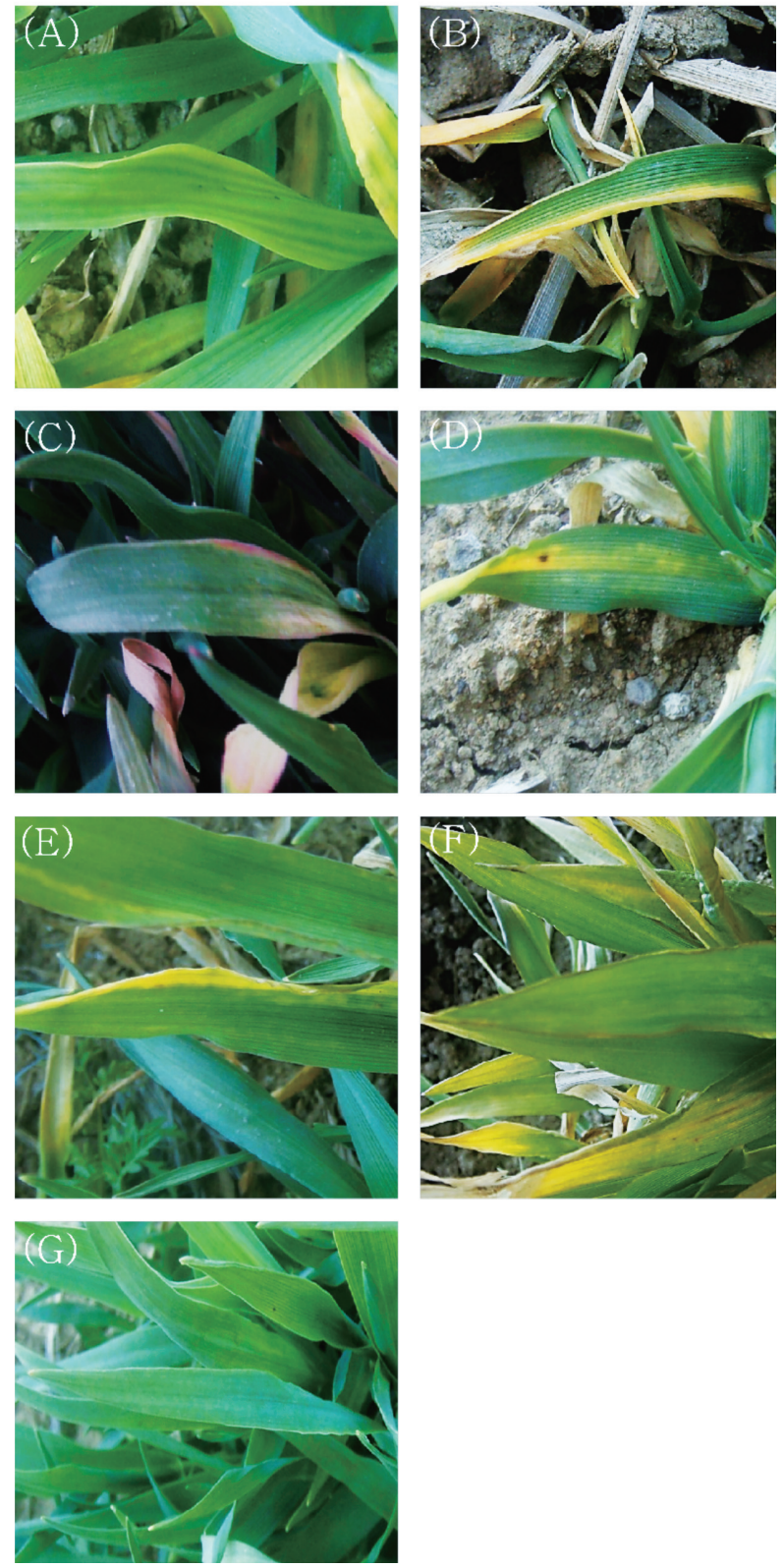

Fig. 2. Symptoms of collected barley samples. BSMV(A); Triple infection of BSMV, BYDV and BaYMV (B); BaMMV (C); BYDV (D); BaYMV (E); Unknown (F); Healthy barley (G).

BSMV-TGB2/3 L149P were similarly substituted into pGDG:MCS after amplification with BSMV-TGB2-F/ BSMV-TGB3-R.

\section{AGROBACTERIUM INFILTRATION, BSMV CONSTRUCTS, AND SUBCELLULAR LOCALIZATION}

All binary vectors used were derived from pGDG as previously described (Goodin et al., 2002). TGB3 and TGB2/3 were amplified from BSMV-WT and BSMV-KR respectively, and inserted to the XhoI and BamHI sites of pGDG. Agrobacterium tumefaciens EHA105 was separately transformed with each pGDG-derived construct; colonies were scraped from fresh plates and diluted to approximately OD600 $=0.5$ in infiltration buffer $(10 \mathrm{mM}$ 
Table 2. Nucleic acid sequence of oligonucleotide primers used for virus detection in this study

\begin{tabular}{|c|c|c|c|c|}
\hline virus & Primer name & Sequence of primer & Accession number & PCR products (bp) \\
\hline \multirow{2}{*}{ BSMV $^{\mathrm{a}}$} & BSMV_beta_cp_F & ACG TTT CTT TGA CTG CTA AG & \multirow{2}{*}{ U35770.1 } & \multirow{2}{*}{299} \\
\hline & BSMV_beta_cp_R & CTT ATC GAG ACG AAA GAA TTT & & \\
\hline \multirow{2}{*}{ BaMMV $^{b}$} & BaMMV_RNA1_cp_F & TCA GGA AAA GAT GAA CCA GA & \multirow{2}{*}{ AF536942.1 } & \multirow{2}{*}{710} \\
\hline & BaMMV_RNA1_cp_R & GTT TCA GTG GTT CTC ATG TT & & \\
\hline \multirow{2}{*}{$\mathrm{BYDV}^{\mathrm{c}}$} & BYDV_F & CAG TCG ACA ACC TTA AAG & \multirow{2}{*}{ HM368370.1 } & \multirow{2}{*}{270} \\
\hline & BYDV_R & TGC TGA TGG TGA AGG AAT TA & & \\
\hline \multirow{2}{*}{ BaYMV $^{d}$} & BaYMV_RNA1_cp_F & GTG TAC CTA AGT CTG TTA TG & \multirow{2}{*}{ AF536958.1 } & \multirow{2}{*}{479} \\
\hline & BaYMV_RNA1_cp_R & GTT ATA CGT TCC AGT TCC AA & & \\
\hline
\end{tabular}

\footnotetext{
${ }^{a}$ Barley stripe mosaic virus

${ }^{\mathrm{b}}$ Barley mild mosaic virus

${ }^{\mathrm{C}}$ Barley yellow dwarf virus

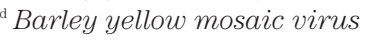

Table 3. Nucleic acid sequence of BSMV specific primers used for sequencing in this study

\begin{tabular}{llc}
\hline \multicolumn{1}{c}{ Primer name } & \multicolumn{1}{c}{ Sequence of primer } & PCR products (bp) \\
\hline BSMV_TGB1_F(5`oligo) & AAACTCGAGAAATGGACATGACGAAAACTGT & 1539 \\
BSMV_TGB1_R(3`oligo) & AAAGGATCCTTATTTGGCCTTGAACCAAC & \\
BSMV_TGB2_F(5`oligo) & AAACTCGAGAAATGAAGACCACAGTTGGTTC & 468 \\
BSMV_TGB2_R(3`oligo) & AAAGGATCCCTAGCCAATATCGCATAGTAA & \\
BSMV_TGB3_F(5`oligo) & AAACTCGAGAAATGGCAATGCCTCATCCC & 479 \\
BSMV_TGB3_R(3`oligo) & AAAGGATCCTTACCTTTTTGAAGAAAGTAAG & \\
\hline
\end{tabular}

MES pH5.6, $10 \mathrm{mM} \mathrm{MgCl2)} \mathrm{containing} 150 \mathrm{mM} \mathrm{3',}$ 5'-dimethoxy-4'-hydroxyacetophenone (Aldrich). When more than one culture was used for co-agroinfiltration, each culture was diluted to OD600 $=0.5$ before adding to the mixture. Bacteria were then incubated at room temperature for $2-3 \mathrm{~h}$ before infiltration with a 1 -cc needleless syringe at the underside of the leaf. Agrobacteria containing pGDG:p19 (a gift of Andy Jackson; Lim et al., 2010) were included at 0.1 volume of all agro infiltration mixes for TGB3 and TGB2/3 expression to minimize silencing and maximize expression. Plants of Nicotiana benthamiana infiltrated with pGDG:TGB3, pGDG: TGB2/3, or pGDG (empty vector) were maintained in a growth chamber at $22^{\circ} \mathrm{C}$.

\section{RESULTS AND DISCUSSION}

\section{DISTRIBUTION OF BARLEY VIRUSES}

For the collection of virus-infected samples, we performed a nationwide survey from March to April, 2015. We collected 83 barley and rye samples in 13 cities, and virus was detected in 10 cities (Gunsan, Iksan, Wanju, Damyang, Yeongwol, Donghae, Samcheok, Uljin, Youngduk, Geumsan). The 20 samples in which BSMV was detected originated in five regions, Jeollabuk-do, Jeollanam-do, Gyeongsangbuk-do, Gangwon-do, and Chungcheongnam-do (Table 4). BSMV was distributed evenly in various regions. Other barley viruses (BaMMV, BYDV, and BaYMV) were detected also. In a previous study, BaMMV and BaYMV were the dominant viruses; however, here we collected samples showing stripe symptoms typical of BSMV, and therefore the rate of BSMV infection was high in this study. The results of investigation showed that the incidence of BSMV was 24.1\%, that of BaMMV was $10.8 \%$, and those of BYDV and BaYMV were $13.3 \%$ and $2.4 \%$, respectively (Table 5). BaMMV, but not BSMV, was identified in one rye sample from Cheonan (Table 4).

\section{SEQUENCE VARIATION OF BSMV MOVEMENT PROTEINS}

To identify the sequence variation of Korean BSMV isolates, the amino acid sequence of the respective triple gene block regions were compared to the homologous sequence of BSMV ND18 strain. There are some minor amino acid differences between BSMV ND18 and some of the Korean BSMV isolates (Fig. 3.). Red boxes indicate the differential amino acids. TGB1 residue 122 Serine is changed to Proline (among 511 total amino acids), TGB2 residue 105 Asparagine is changed to Aspartic acid, and TGB3 residue 149 Leucine is changed to a Proline residue in some of the Korean sequences. On the whole, the newly isolated Korean BSMV showed high sequence homology to previously reported US isolate ND18.

Some isolates from the two provinces Jeollabuk-do and Gyeongsangbuk-do showed sequence variation. There are two variant clones among 20 cloned TGB1 amplicons which were derived from Jeollabuk-do. There 
were also two TGB2 variant clones among 21 derived from samples collected in Jeollabuk-do and Gyeongsangbuk-do. TGB3 segment showed the highest rate of variant clones, with 11 Korean isolate variant TGB3 segments among total 24 collection samples (Table 6).

Table 4. Locations of collection of barley tissue samples and RT-PCR results

\begin{tabular}{|c|c|c|c|c|c|c|}
\hline \multirow{2}{*}{ Sample No. } & \multirow{2}{*}{$\begin{array}{l}\text { Location } \\
\text { (province) }\end{array}$} & \multirow{2}{*}{ Date } & \multicolumn{4}{|c|}{ Viruses detected } \\
\hline & & & $\mathrm{BSMV}^{\mathrm{a}}$ & BaMMV $^{\mathrm{b}}$ & $\mathrm{BYDV}^{\mathrm{c}}$ & BaYMV $^{\mathrm{d}}$ \\
\hline H0005, H0007 & Iksan (Jeollabuk-do) & $2015-03-10$ & $\bullet$ & & $\bullet$ & $\bullet$ \\
\hline H0009 & Wanju (Jeollabuk-do) & $2015-03-10$ & & & $\bullet$ & \\
\hline H0011 & Wanju (Jeollabuk-do) & $2015-03-10$ & $\bullet$ & & & \\
\hline H0017 & Damyang (Jeollanam-do) & 2015-03-10 & $\bullet$ & & & \\
\hline H0022 (rye) & Cheonan (Chungcheongnam-do) & 2015-03-14 & & $\bullet$ & & \\
\hline H0033 H0040 & Sangju (Gyeongsangbuk-do) & $2015-03-17$ & & $\bullet$ & $\bullet$ & \\
\hline H0050, H0052 & Donghae (Gangwon-do) & 2015-03-24 & $\bullet$ & & & \\
\hline H0065 & Samcheok (Gangwon-do) & 2015-03-24 & $\bullet$ & & & \\
\hline H0066 H0067 & Uljin (Gyeongsangbuk-do) & $2015-03-24$ & $\bullet$ & & & \\
\hline H0071 H0078 & Uljin (Gyeongsangbuk-do) & $2015-03-24$ & $\bullet$ & & & \\
\hline H0080 H0082 & Geumsan (Chungcheongnam-do) & $2015-03-28$ & $\bullet$ & & & \\
\hline
\end{tabular}

${ }^{a}$ Barley stripe mosaic virus

${ }^{\mathrm{b}}$ Barley mild mosaic virus

${ }^{\mathrm{C}}$ Barley yellow dwarf virus

${ }^{\mathrm{d}}$ Barley yellow mosaic virus

Table 5. Prevalence of barley virus infection

\begin{tabular}{cccccc}
\hline & No. of samples & BSMV $^{\mathrm{a}}$ & BaMMV $^{\mathrm{b}}$ & BYDV $^{\mathrm{c}}$ & BaYMV $^{\mathrm{d}}$ \\
\hline Total No.(\%) & 83 & $20(24.1)$ & $9(10.8)$ & $11(13.3)$ & $2(2.4)$ \\
\hline
\end{tabular}

${ }^{\text {a } B a r l e y ~ s t r i p e ~ m o s a i c ~ v i r u s ~}$

${ }^{\mathrm{b}}$ Barley mild mosaic virus

${ }^{\mathrm{c}}$ Barley yellow dwarf virus

${ }^{ }$Barley yellow mosaic virus

Table 6. Detected BSMV isolate variants and distribution in three regions of Korea in 2015

\begin{tabular}{|c|c|c|c|}
\hline ORF & Changed amino acid & Region (Korea) & $\begin{array}{l}\text { Korean unique sequence/Total number of } \\
\text { clones sequenced per gene construct }\end{array}$ \\
\hline TGB1 & 122 Serine $\rightarrow$ Proline & Jeollabuk-do & $2 / 20$ \\
\hline TGB2 & 105 Asparagine $\rightarrow$ Aspartic Acid & $\begin{array}{l}\text { Jeollabuk-do, } \\
\text { Gyeongsangbuk-do }\end{array}$ & $2 / 21$ \\
\hline TGB3 & 149 Leucine $\rightarrow$ Proline & $\begin{array}{l}\text { Jeollabuk-do, } \\
\text { Gyeongsangbuk-do }\end{array}$ & $11 / 24$ \\
\hline
\end{tabular}

TGB1

BSMV ND18 : MDMTKTVEEKKTNGTDSVKG . . . . SSQQVGENVSENYTGISK.....EDHSWFKA

BSMV KR : MDMTKTVEEKKTNGTDSVKG . . . . SEQVGENVSENYTGISK.....EDHSWFKA

TGB2

BSMV ND18 : MKTTVGSRPNKYWPI....GDSGGNNSCGEDCQGECLNGHSRRSLLCDI

BSMV KR : MKTTVGSRPNKYWPI.....GDSGGDNSCGEDCQGECLNGHSRRSLLCDI

TGB3

BSMV ND18 : MAMPHPLECCCPQCLPSSESFPIYGE_.SSVLLKPLTLVFALSFF $149 \quad 154$

BSMV KR : MAMPHPLECCCPQCLPSSESFPIYGE.....SVLLKPLTLVFALSFFELLSSK

Fig. 3. BSMV ORF amino acid alignments of Korean isolate (KR) and the ND18 (WT) isolate. 


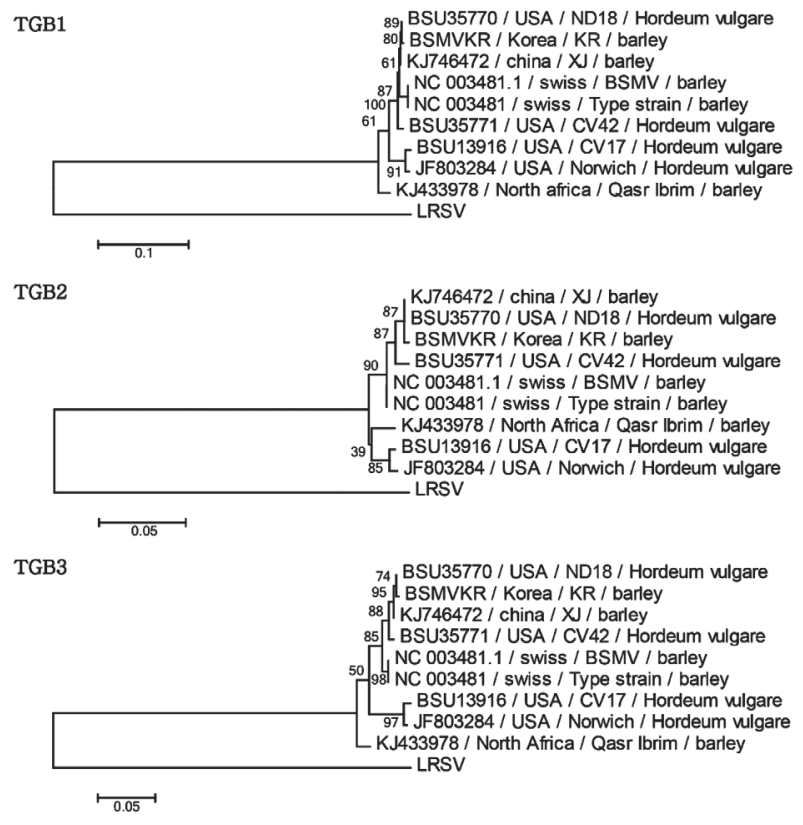

Fig. 4. Phylogenetic tree of BSMV ORFs (TGB1, TGB2, and TGB3). Bootstrap values of 1000 replicates in phylogeny test. Korean BSMV strain shares the highest degree of identity with ND18.

\section{THE PHYLOGENY OF THE MOVEMENT PROTEIN SEQUENCES}

The phylogeny of the movement protein sequences showed that BSMV ND18 and Korean strain are highly related. BEAST analysis of all extant and Korean BSMV strains was performed using an epidemiology model. The topology of BSMV phylogenetic trees using this model is consistent for each gene segment using the equivalent sequence of the related Lychnis ringspot virus as an outlier to root the tree (Fig. 4). There was little variability between the ND18 and Korean strains. The newly isolated Korean BSMV showed high sequence homology to previously reported US isolates in all three respective ORFs.

\section{SUBCELLULAR LOCALIZATION PATTERNS OF TGB3}

In this study, we have investigated the properties of BSMV TGB3 protein and also examined the subcellular localization patterns of TGB3 fusion proteins expressed in $N$. benthamiana leaf cells by agro infiltration. Cells were examined by confocal microscopy at 3 days after

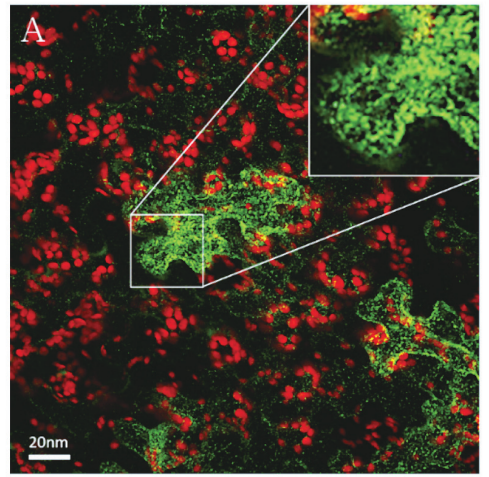

ND18

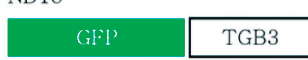

GB3
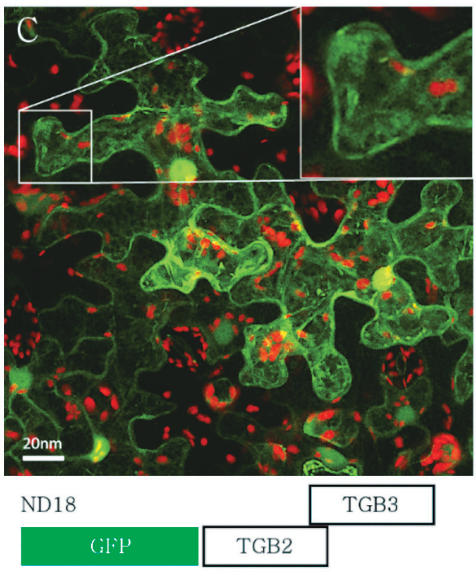

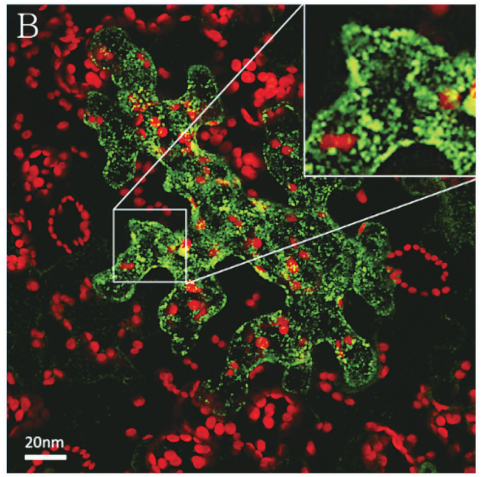

Korean Isolate
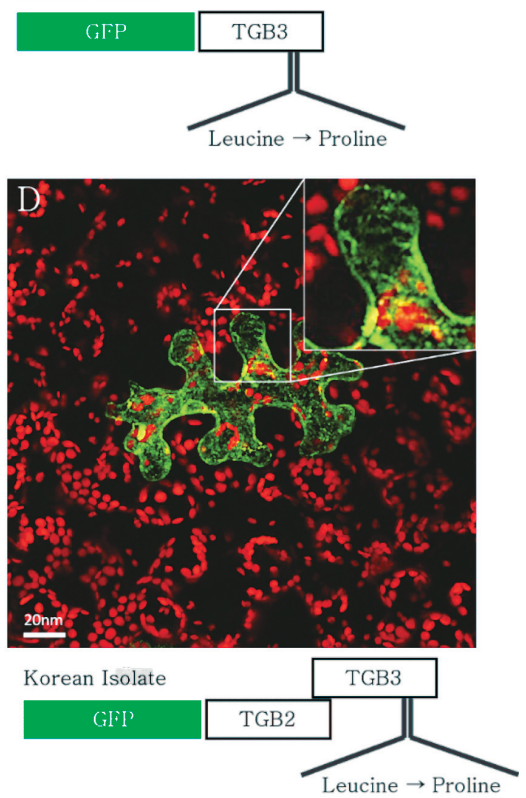

Fig. 5. Subcellular localization of TGB3 and TGB2/3 mutants in agroinfiltrated $N$. benthamiana leaf cells. Shown are appearances of leaf cells co-expressing GFP-TGB3 and GFP-TGB2/3 mutants and p19. (A) GFPTGB3-WT, (B) GFP-TGB3-KR, (C) GFP-TGB3-WT, (D) GFP-TGB2/3LP. Chloroplast autofluorescence is shown as red, mainly from the underlying mesophyll cells. Bars, $20 \mu \mathrm{m}$. 
inoculation (Fig. 5). The newly isolated Korean BSMV was compared with ND18 strain previously reported in USA. We have not identified any differences in subcellular localization between BSMV TGB3 wild type and Korean isolate (L149P). There was a 'peppering' pattern of expression in BSMV TGB3 WT and KR located in the cytoplasm and at the cell wall, and a streaming effect was observed when samples were heated with a UV source. Localization of BSMV wild type TGB2/3 (GFP:TGB2, with TGB3 also expressed) was located in the cytoplasm at the cell wall, and at the nucleus. In contrast, no nuclear association was observed for BSMV KR TGB2/3, and the expression level was consistently reduced compared to WT TGB2/3.

\section{CONCLUSIONS}

BaYMV has been reported to be the dominant virus in barley in Korea, and BaMMV has also been reported to cause yield reductions. Both BYDV and BSMV have been reported at low percentages of infection. In this study, we collected barley and rye samples with BSMV-like symptoms such as stripe and stunt from newly-cultivated barley and rye fields to maximize detection of seedtransmitted viruses; however, BSMV was not detected in any of the symptomatic rye samples. Because samples were collected on the basis of stripe and stunt symptoms typical of BSMV, the infection percentage of BSMV was the highest at $24.1 \%$, with BaMMV at $10.8 \%$, BYDV at $13.3 \%$, and BaYMV at $2.4 \%$, respectively. The results of BSMV triple gene block sequence analysis revealed one changed amino acid residue in each of TGB1, TGB2, and TGB3 compared to the most closely related ND18 isolate. The newly characterized Korean BSMV isolates have little sequence variability and it showed high sequence homology to previously reported US isolates (especially ND18). We identified no significant difference between BSMV strain ND18 and BSMV Korean isolate by analyzing sequence variation and subcellular localization,. We can apply these results to develop an efficient management plan for barley viruses, to confirm distribution of common viruses and possible control measures.

Further work will concentrate on construction of infectious clones based on the Korean variant sequences, in which the TGB1, TGB2 and TGB3 variants will be assembled in various combinations to evaluate whether the single residue mutations in each gene affect isolate characteristics individually or in combination. Additional experiments will be carried out to identify the possible agents involved in the symptoms of the many symptomatic plants in which none of the four viruses tested for (BSMV, BaMMV, BaYMV, and BYDV) were detected. Candidates for further testing include geminiviruses, potyviruses, and Rice stripe virus that may potentially be emerging in barley crops in Korea.

\section{ACKNOWLEDGEMENT}

This research was supported by iPET (Korea Institute of Planning and Evaluation for Technology in Food, Agriculture, Forestry and Fisheries), Ministry of Agriculture, Food and Rural Affairs (Project No. 1130443) and carried out with the support of Cooperative Research Program for Agriculture Science and Technology Development (Project No. PJ01007703201401), Rural Development Administration, Republic of Korea.

\section{REFERENCES}

Barr, D. J. S. and Slykhuis, J. T. 1976. Further observation on zoosporic fungi associated with wheat spindle streak mosaic. Can. Plant Dis. 556: 77-81

Chen, J., Swaby, A. G., Adams, M. J. and Ruan, Y. 1991. Barley mild mosaic virus inside its fungal vector, Polymyxa graminis. Ann. Appl. Biol. 118: 615-621

Frahm, J. H. 1989. Reduced yield caused by BaYMV - in Lippe, Westphalia an analysis of causal factors. Gesunde Pflanzen. 41: $45-46$

Goodin, M. M., Dietzgen, R. G., Schichnes, D., Ruzin, S. and Jackson, A. O. 2002. pGD vector: versatile tools for the expression of green and red fluorescent protein fusions in agroinfiltrated plant leaves. Plant J. 31(3): 375-383

Ha Y. Y. 1999. Malting barley virus diagnosis and development of resistance gene tracing techniques using molecular and cell-biological method. Ministry of Agriculture and Forestry

Han, J.-Y., Kim, J.-K., Cheong, J.-S., Seo, E.-Y., Park, C.-H., Ju, G.-K., Cho, I. S., Gothoh, T., Moon, J. S., Hammond, J., Lim, H.-S. 2015. Survey of Apple Chlorotic Leaf Spot Virus and Apple Stem Grooving Virus Occurrence in Korea and Frequency of Mixed Infections in Apple. J. Fac. Agr., Kyushu Univ. 60 (2): 323-329

Kojima, M., Matsubara, A., Yanase, S. and Toriyama, S. 1983. The occurrence of barley yellow dwarf disease in Japan. Ann. Phytopath. Soc. Japan. 49: 338-346

Lim. H.-S., Bragg, J. N., Ganesan, U., Lawrence, D. M., Yu, J., Isogai, M., Hammond, J. and Jackson, A. O. 2008. Triple gene block protein interactions involved in movement of Barley stripe mosaic virus. J. Virol. 82: 4991-5006

Lundsgaard, T. 1976. Routine seed health testing for barley stripe mosaic virus in barley seeds using the latex-test. J. of Plant Disease and Protection. 83(5): 278-283

Jeżewska, M. and Trizmiel, K. 2009. Impact of seed-transmitted viruses on quality of cereal seeds. Journal of plant protection research. $\mathbf{4 9}(4)$ : 460-464

Na, Y. J. 1979. Serological detection of barley stripe mosaic virus infection in the seeds of barley and wheat cultivars grown in Korea. Kor. J. Plant Protect. 18(1): 29-33

NICS (National Institute of Crop Science). RDA(Rural Development Administration). 2011. 2014. Study on occurrence and damage to disease and pest of crops by climate change. PJ008734. $42-53$

Park, J. C., Noh, T. H., Park, C. S., Kang, C. S., Kang, M. H., Lee, E. S., Lee, J. H., Lee, J. J., Kim T. S. 2009. Responses of Resistant Genes to Barley Yellow Mosaic Virus (BaYMV) strains in Korea. Res. Plant Dis. 15(2): 72-76

Slykhuis, J. T. 1976. Virus and virus-like diseases of cereal crops. Annu. Rev. Phytopathol, 14(1): 189-210

So, I.-Y., Lee, K.-J., Chon K.-H., Seo, J.-H. $1997 . \quad$ Distribution and Screening for Barley Cultivars Resistance to Barley Yellow Mosaic Virus and Barley Mild Mosaic Virus in Southern Korea. Korea J. Plant Pathol. 13(2): 118-124

Tamura, K., Stecher, G., Peterso, D., Filipski, A., Kumar, S. 2013. MEGA6: molecular evolutionary genetics analysis version 6.0. Mol.Biol. Evol, 30(12): 2725-2729 